\title{
Matching Contemporary Linguistic Realities in Multilingual Societies: An Analysis of Nigeria's Language Education Policy
}

\author{
Chioma Ezeh \\ College of Education, Washington State University, Smith Center for Undergraduate Education, 303D, Pullman, \\ WA 99164, USA \\ * E-mail of the corresponding author: chioma.ezeh@wsu.edu
}

\begin{abstract}
The major rationale behind bilingual education is that native languages are resources that can be used to make learning accessible to all learners in bilingual contexts, and that also deserve to be developed for learners to be bilingually skillful for 21st century global competitiveness. While there exist different bilingual education models that have been used to serve bilinguals in different contexts, recent scholarship suggest that dynamic bilingual education is more approximate to achieving the goals of bilingual education. This article aimed at reviewing the various provisions that Nigeria, a typical multilingual society, has made to utilize and expand the linguistic resources that its linguistically diverse students bring to school. A critical analysis of its national language education policy and its implementation revealed that Nigeria has partially taken a resource-oriented approach to language by welcoming and recognizing the resourcefulness of native languages in fostering school learning. However, it has a systemic aim to transition students to all-English instruction. Developing and using students' native languages for instruction last only at the lower primary school level and become optional afterwards. It was also found that what is spelt out in the nation's language policy is far from what is implemented in schools. Such findings necessitate that the nation gives primacy to its rich linguistic resources, devise accountability measures for states and schools, and consider developing a comprehensive dynamic bilingual education policy that matches its linguistic realities.
\end{abstract}

Keywords: language policy, multilingual societies, linguistic pluralism, dynamic bilingual education

DOI: $10.7176 / \mathrm{JEP} / 12-5-03$

Publication date: February $28^{\text {th }} 2021$

\section{Introduction}

Multilingualism has characterized virtually all nations of the world. Nigeria is a typical multilingual society with about 500 native languages are in existence in Nigeria, with English as the official language (Vanguard, 2010). In addition to the multiple languages and English used in Nigeria is an English-based Creole called Pidgin which has many speakers (United Nations Educational Scientific and Cultural Organization (UNESCO), 2003). These rich linguistic resources are not only valuable assets that should be preserved and allowed to expand, but also a vehicle through which the potentials of the nationals could be driven to its fullness. Language is a chief actor in determining the future any nation's education. It is one thing to have linguistically diverse students, but another to provide them with an education that meets their needs as people who have complex linguistic repertoires. Every meaningful educational endeavor starts with acknowledging linguistic and cultural resources that learners bring to school and aims at meeting the individual needs of learners (Crawford, 2004; Woodward, 2001). Whether a learner will succeed academically or not depends on the language of instruction used in schools. Moreover, the school as a significant social institution determines whether bilinguals' native languages are to be valued and maintained or lost (Johnson \& Johnson, 2015).

The resourcefulness of languages goes beyond its academic benefits and extends to its role in globalization today. Developing bilingual/multilingual capacities in learners is a needed skill for the advancement of global economy, cultural enrichment, and preparation of learners for life in a diverse world (Crawford, 2004; Ruiz, 1988). The language situation in diverse contexts has always necessitated the adoption of an education language policy that would embrace language diversity and language use as an invaluable human asset. The way this reality - linguistic pluralism - is perceived and handled has differed in various countries. While some countries have approached this reality positively by enacting bilingual education language policies that are resourceoriented, others have taken a problem-oriented approach (Ruiz, 1988). Research on bilingual education have emphasized the need for policies and educational agencies to accommodate the linguistic and cultural resources - funds of knowledge that linguistically diverse students bring to school (Avineri et al., 2015; Johnson 2009, 2015; Rolstad \& Macswan, 2008; Sayer, 2008; Wiley \& Rolstad, 2014; \& Zentella, 2002). This is where bilingual education has an all-important function to play if bilingual students are to succeed academically, and if their native languages and cultures are to be developed and preserved. Moreover, bilingual education has been interpreted and modeled differently by different countries in their language policies. Not all models of existing bilingual education are appropriate in addressing linguistic diversity in diverse contexts. Each context or country must develop a model that suits its linguistic landscape and ques into global understanding of language diversity. 
The important question facing educational language policy makers and educators in linguistic pluralistic societies has been what the language of instruction should be in order to ensure academic success of all learners and preserve native languages of language-minority/bilingual youngsters. Nigeria has a centralized federal language policy that exists as an appendage to the national educational policy and has not been reviewed or update since 2004 (UNESCO, 2006). While the policy in general seems to be language-as-resource oriented as it recognizes the value of native language to an extent, it has some aspects that conflict with not only this orientation, but also effective practices for linguistically diverse students. This article reviews how Nigeria - a multilingual society have addressed linguistic pluralism through language education policy. Specifically, its language policy is analyzed in the light of what bilingual education provisions are in place to academic success of and develop the bilingual skills of its linguistically diverse students. In what follows, an overview of bilingual education and its current conceptualizations (that is, dynamic bilingual education) is offered. Following that, this article presents the methodology used to retrieve policy documents, a critical review and analysis of Nigeria language education policy and its implementation. The article ends with a conclusion where the findings are discussed and major recommendations that address the challenges found in the planning and implementation of the policy are offered.

\section{Bilingual Education in Multilingual Societies}

Bilingual education is broadly defined as an educational program where two languages are used in classroom instruction to enhance academic success of bilingual/language-minority students (Crawford, 2004). The concept of bilingual education is deeply rooted in language-as-resource orientation (Johnson \& Johnson, 2015). Three aims of bilingual education include 1) aiding bilinguals' acquisition of the second language; 2) advancing learning in other subject areas through native language instruction; and 3) developing and maintaining students' cultural identities and native languages (Jong, 2006). In contrast to single-language-based programs such as allEnglish programs, bilingual students' first/native languages are acknowledged as valuable resources that need not only to be used to make instruction comprehensible, but also to be maintained in bilingual education programs.

Multilingual countries that have bilingual education policies are language-as-resource-oriented. Language orientation is the framework behind societies' attitude and ideology toward language and its role (Ruiz, 1988). In multilingual nations, what is often obtainable is a dominant language existing alongside several indigenous languages. The language policy of any country reflects of its language disposition. Language orientation determines how the different languages that coexist in the same geographical space will be treated. Following Ruiz's (1988) categorization of language orientations, education language policies that aim at promoting academic success while maintaining indigenous languages (bilingual education policies) take a language-asresource approach toward language policy planning and reforms, while policies that focus on remedying native languages and ensuring that bilingual students transition to a dominant and more glorified language (all-English program policies) are language-as-problem-oriented. An important aspect of resource-oriented policies (bilingual education policies) is the development and conservation of native language skills (Ruiz, 1988).

Given the diverse nature of the world, and the role of bilingual/multilingual capacity and knowledge of the world's diverse cultures in globalization, resource-oriented policies are called for (Ngai, 2002; Ruiz, 1988; Odugu, 2011; Vance, 2004). Globalization is a central concern in the world today. Human social organization relies on language for communication, both locally and internationally (Odugu, 2011; Vance, 2004). Governments and educational systems of countries such as Switzerland, Canada, Byelorussia, and Belgium that have recognized the resourcefulness of languages in the world today have actively supported bilingualism (Vance, 2004). Beyond educational gains of bilingual ability such as increased learning and skill expansion, bilingualism contributes immensely to the development of globalization (Ruiz, 1988). Ruiz (1988) states that language skills are instrumental in trans-national affairs, military preparedness and national security, diplomatic functions, international trade, and enhancing peace amongst intergroup.

In response to multilingualism, bilingual education has been interpreted differently in language policies of different states/countries, and as such, has different models. Even, Crawford (2004) posits that some approaches are more successful in practice than others. Approaches that emphasize a gradual transition to the second language and the development of bilinguals' native languages alongside the second language have been proven to yield better results (Crawford, 2004). Three major approaches to bilingual education include transitional bilingual education (TBE), developmental bilingual education, and two-way bilingual education (Crawford, 2004; Rolstad, Mahoney \& Glass, 2005).

Following Crawford's categorization of bilingual education models, transitional bilingual education (TBE), known as the early-exit bilingual education is the least successful. The goal is to expedite bilinguals' transition into all-English mainstream classrooms while disarming them of and remedying their native language skills (Alanis, 2000; Crawford, 2004). Applied linguists have questioned the effectiveness of this model and have argued that it is non-bilingual (Alanis, 2000). In no way does it promote the development and maintenance of 
students' native languages. Bilinguals receive instruction in English and native-language-support for the period they lack proficiency in the second language and are speedily moved to all-English regular classrooms as soon as they have acquired English skills needed to function in such an atmosphere (Alanis, 2000; Crawford, 2004; López \& Tashakkori, 2006; Lara-Alecio, et al., 2004; Rolstad et al., 2005; Villarreal, 1999). Bi/multilingual students last in the program for a period of $2-4$ years (Crawford, 2004). Because quick transition to English is emphasized in this approach and no attempt is made in developing native languages, it is subtractive in nature (Alanis, 2000; Crawford, 2004; Lara-Alecio, et al., 2004). This model may only strive to improve the academic achievement of bilinguals but fail to develop other latent potentials they need to succeed in the $21^{\text {st }}$ century world (Crawford, 2004; Villarreal, 1999).

Ranking programs according to their effectiveness, developmental bilingual education (DBE), called lateexit or gradual-exit bilingual education is a better approach of bilingual education compared to transitional bilingual education (Crawford, 2004). Although it is also transitional in nature, it is described as a better approach because it recognizes the importance of native languages in making instruction comprehensible, and as resources that are worth being developed and maintained (Crawford, 2004; Rolstad et al., 2005). Bilinguals are allowed 5 - 6 years' time to gradually develop English language skills before they are moved into all-English mainstream classes (Crawford, 2004).

The third approach to bilingual education is the two-way bilingual education, also called dual immersion, dual language, or two-way immersion. So far, it is ranked the best bilingual education model because it does not only make learning accessible to bilinguals through native language instruction, but also promotes bilingualism and biliteracy (Alanis, 2000; Crawford, 2004; Lara-Alecio, et al., 2004; López \& Tashakkori, 2006; Marian et al., 2013; Murphy, 2014; Senesac, 2002). In addition, native languages are not withdrawn from instruction in most cases (Murphy, 2014). Two-way bilingual education is practiced differently in different settings. Two common models are 50/50 or simultaneous dual language model and 90/10 or sequential dual language model (Berens et al., 2013; Crawford, 2004). In the 50/50 model, equal amount of time is given for instruction in all subject areas in the native language and English (Berens et al., 2013; Crawford, 2004; Lara-Alecio, et al., 2004). Conversely, in the 90/10 model, native language instruction is first provided for English learners at the start of the program when they are limited-English-proficient, while the second language is introduced gradually (Berens, Kovelman, \& Petitto, 2013; Crawford, 2004; Lara-Alecio, et al., 2004).

\subsection{Dynamic Bilingual Education for Contemporary Linguistic Realities}

While most existing models of bilingual education, particularly, the two-way bilingual education, have been shown to work in some contexts, recent research and conceptualization of bilingual education question them for neither reflecting the real-world fluid language practices of bilingual communities nor matching contemporary social and linguistic realities of the globalized world. The major flaw of existing bilingual programs is that bilingualism and language education are still understood conceptualized through a monoglossic ideology that seeks language uniformity and purism. Recent scholarship calls for heteroglossic ideologically oriented dynamic bilingual education policies and practices to address the linguistic pluralism and educational inequities in the $21^{\mathrm{st}}$ century multilingual classrooms. A heteroglossic ideology sees all languages and language practices as legitimate, understands the inherent diverse nature of language and that diverse language practices embody its users' lived experiences and soiciocultural histories. Dynamic bilingual education, as a kind of heteroglossic practice, involves practices that allow bilinguals to engage their real world full linguistic repertoires in order to meet their language, sociocultural and academic needs. The needs of emergent bilinguals may never be addressed unless the language education policies that service them are systematically disengaged from a monoglossic language ideological orientation (Flores \& Schissel, 2014; Hornberger, 2005). That is, to enable linguistically diverse students to make sense of their world, language policies must allow students to negotiate challenging academic content with their fluid/dynamic language practices that reflect their full linguistic repertoires while encouraging their emerging bilingualism (Cummins, 2017; García \& Sylvan, 2011).

A heteroglossic language orientation comes from an ideology that espouses dynamic bilingualism as the norm and supports a dynamic approach to bilingualism that cognizes the emergent bilinguals' authentic dynamic meaning-making discursive practices (Garcia, 2009; Flores \& Schissel, 2014; Khote \& Tian, 2019). Linguistically diverse students are more likely to succeed in school when their language and literacy practices are valued and aligned with school practices (Faltis, 2005). Embedded in their linguistic repertoires are strengths and skills that schools can recognize and build upon to help them reach their potentials (Johnson, 2015). However, these opportunities are missed when language policies confine students to only one standard language or discrete use of two named languages. Education in multilingual communities must reflect the linguistic realities of its bilingual students and give them opportunity to exploit their ingenuity and latent skills that prepare them for global competitiveness. 


\section{Methodology}

As the aim of this work was to understand ways in which Nigeria, as a multilingual society has addressed linguistic pluralism through its language education policies, two kinds of data, demographics data and language policy data, were relevant to this article. Knowledge of the demographics of the country was necessary to understand the implications bilingual education policy models that exist or are needed in the country. Hence, data for Nigeria demographics were sourced from World Education News \& Reviews (WENR) (2004), Vanguard (2010) and Nigerian Muse (2010). Important to this research was understanding the kind of provisions that are made in Nigeria language policy to serve its linguistically diverse population. In this regard, data about the language policies were needed for analysis. Nigeria language policy data were majorly obtained from United Nations Educational Scientific and Cultural Organization (UNESCO) website. Specifically, data were derived from Strategies for Introducing New Curricula in West Africa, Nigeria Education Sector Diagnosis by Education Sector Analysis Unit of Federal Ministry of Education, and World Data on Education in UNESCO (2003, 2005, $\& 2006)$ respectively. Some data on Nigeria language policy were also obtained from Vanguard (2010). The policy, as well as its implementation, was reviewed and analyzed based on the conceptualizations of dynamic bilingual education that matches the linguistic realities of multilingual societies.

\subsection{Analysis}

As part of the analysis of Nigeria language policy, it is pertinent to understand its language demographics. Presented in the following section is an overview of the linguistic heterogeneous contexts of Nigeria which demonstrates a need for language policies that address bilingualism/multilingualism.

\subsection{Nigeria Demographics}

Nigeria is a multi-ethnic/lingual nation made up of more than 250 ethnic groups with different languages (World Education News \& Reviews, 2004). Although the specific number of ethnic groups in the country is unknown, 250 is the common estimation (Nigerian Muse, 2010). The result of research conducted by Nigeria National Education Research Development Center (NERDC) on language demographics of Nigeria revealed that there are about 500 languages in existence in Nigeria (Vanguard, 2010). In its diverse population, three ethnic groups: Hausa-Fulani, Yoruba and Igbo are most politically influential, and their languages have been declared the national languages with a generic term 'wazobia' (Nigerian Muse, 2010). They make up over 50\% of the entire population: Hausa-Fulani 29\%, Yoruba 21\%, and Igbo 18\%. According these three languages of the major ethnic groups the statuses of national languages have always aroused fear of domination in other minority groups. Other ethnic groups are accorded a minority status in different degrees (Nigerian Muse, 2010). For instance, Ijaw, Efik, Kanuri, Edo, Ibibio, Nupe and Tiv are large minority groups with millions of members (Nigerian Muse, 2010). Amidst the existence of multiple native languages in Nigeria, English is the country's official language and is spoken widely (WENR, 2004). With the multiplicity of ethnic groups and languages in Nigeria, the English language has served the function of fostering national unity and understanding in the country right from the colonial era to post independence era (Danladi, 2013). It is the language used for government functions and in official circles. As a matter of fact, with the status it has been ascribed in the country, it exerts a dominating influence over Nigerian languages. It is the first in the language hierarchy of Nigeria followed by the three national languages (Odugu, 2011). In addition to the multiple native languages and English spoken in Nigeria, an English-based Creole called Pidgin also exists and is the language commonly used in some environments (UNESCO International Bureau of Education (IBE), 2003). Ostensibly, in such a linguistically diverse context and with English as the country's official language, every citizen is potentially bilingual. Every Nigerian speaks at least two languages: a native language, plus English or an English-based Creole called Pidgin. In effect, the diversity is reflected in the classrooms. The map in Figure 1, which reflects Nigeria geographical map, depicts Nigeria's linguistic pluralism. Subsequently, its language education policy is analyzed to see how linguistic pluralism is addressed to match the nations' linguistic landscape. 


\section{Linguistic Groups}

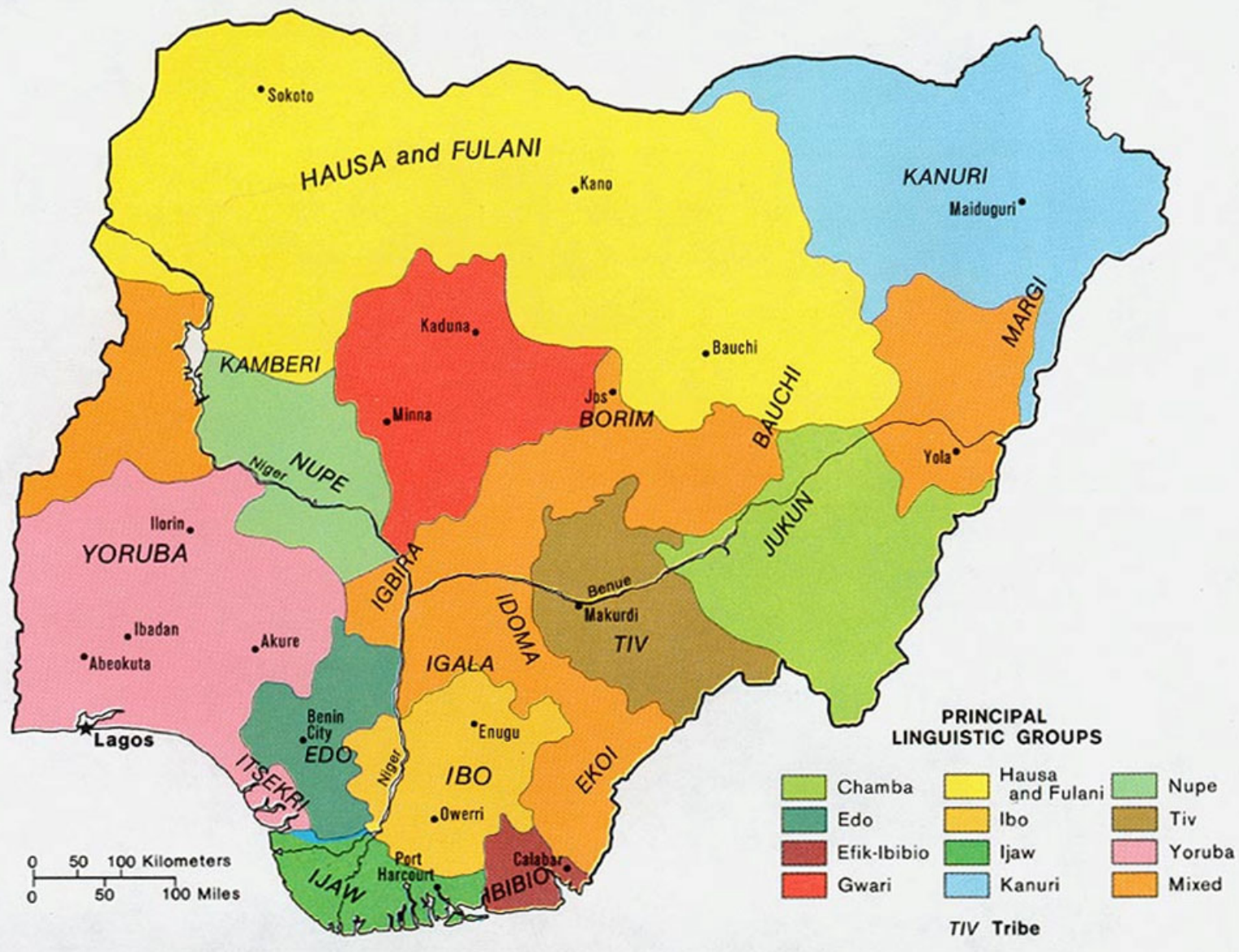

Figure 1. Linguistic demographics of Nigeria

\subsection{How is Linguistic Pluralism Addressed in Nigeria's Language Education Policy?}

Multilingual states/countries have different ways they have addressed language pluralism. While some have taken a problem-oriented approach in language policy planning, others have taken a resource-oriented step by adopting bilingual education. In this section of the article, the language policy of Nigeria is analyzed with the to understand what provisions are in place to meet the educational needs of its linguistically diverse student population, as well as preserving the linguistic skills they bring to school.

In Nigeria, there is only one Federal language policy for all states and schools in the federation. The Federal Ministry of Education is vested with the responsibility of formulating and harmonizing educational policies of the nation through the National Council of Education (NCE), the highest policy-making body in matters of education (UNESCO, 2006). In Nigeria's case, it can be said that language education policy has not been given the kind of attention it deserves (Vanguard, 2010). Till date, Nigeria has no structured and comprehensive language policy; its language policy is only an appendage in the National Policy on Education. Compiling a national language policy continues to be a topic of discussion without any actions (Vanguard, 2010). Seemingly, Nigeria may be said to have partially taken a resource-oriented approach to language policy planning as its policy speculations places English at a higher advantage than the vast languages and language resources in the country. Its language policy speculates that the medium of instruction at the first three years of a child's preprimary education and first three years of primary school (grades $1-3$ ) education should be the mother tongues or language of the immediate community (UNESCO, 2006).

Also, provisions are made in the policy for the development of both English language and native language skills of its linguistically diverse students at the pre-primary school and primary school (UNESCO, 2006). This is a vital aspect of bilingual education. The rationale behind bilingual education includes making learning accessible to all learners through the use of native languages and developing their skills in both languages (Crawford, 2004; Jong, 2006). As stated in the policy, English and Nigerian languages are taught as subjects at the pre-primary school and primary school levels. In the pre-primary school, six thirty-minute periods are allocated to the teaching of English, while the teaching of the native language is given two periods in a week 
(UNESCO, 2006). In grades 1-6, that is, the primary school, the time devoted to teaching English increases to thirty-five minutes per day for the five school days in a week and the native language or language of immediate community is continually taught as a subject (UNESCO, 2006). Obviously, this policy can be labeled as a developmental bilingual education model, in the sense that native languages are recognized as resources that aid learning and that are worth to be developed but with a short-term goal (Crawford, 2004; Rolstad et al., 2005). While the policy accommodates bilingualism, the major goal is to transition students to all-English instruction.

Nigeria language policy is transitional. Bilingual education research scholars criticize early withdrawal of the native language instruction (Ojetunde, 2012; Vanguard, 2010). The maximum duration of time a student can receive native language support and development lasts only a little while compared to the emphasis placed on English which is even a foreign language. Nigeria policy does not specify how to ascertain when a learner is fit for the all-English instruction in the upper primary. An issue that is worth maximum attention in educational matters is learner differences (Crawford, 2004; Woodward, 2001). There is no measure to determine when students are ready for all-English classrooms, as all learners are moved into all-English classrooms at the completion of lower primary school. Educational stakeholders in Nigeria have attributed educational underachievement in Nigeria to the early termination of native language instruction (Vanguard, 2010). It is thought that students fail to comprehend instruction as a result of linguistic deficiencies. It is recommended that native language instruction should be extended to the end of junior secondary school, that is, students should be taught in their mother tongue for the first twelve years of their education (Vanguard, 2010).

Nigeria language policy faces implementational challenges in the aspect of language of instruction. The policy specifies that the medium of instruction at pre-primary school and first three years of primary school should be the native language of a child or the language of immediate community. However, the implementation of bilingual instruction in the country is uneven. In a study undertaken by the Education Sector Analysis (ESA) Unit in collaboration with the Federal Ministry of Education and some development partners to analyze the problems and constraints in the education sector, 884 pre-primary schools and 970 primary schools, both public and private schools, across the thirty-six states of the country were sampled. The findings of the study revealed that the language of instruction at the pre-primary schools sampled was widely English with $71.2 \%$, followed by the language of the immediate environment (26.6\%), and Pidgin, being the least used (ESA Unit Federal Ministry of Education, 2005). The same trend was obtained at the primary schools. The language of instruction in primary $1-3$ was English in 437 (44.1\%) sampled schools, Pidgin in 20 (2.0\%), local languages in 357 $(36.0 \%)$, and the language of the immediate community in $189(19.19 \%)$ of the sample (ESA Unit Federal Ministry of Education, 2005).

Based on this report, a good number of children are taught in English at their first 6 years of education contrary to the speculation in the national language policy. The ESA Unit attributes the situation to a trend in society whereby many parents desire their children to speak English as soon as they are enrolled in the preprimary school, many parents speak English to their children at home even if not in a standard and intelligible form, and the fact that some of the languages of the local communities of the schools are yet to have orthographies (ESA Unit Federal Ministry of Education, 2005). This situation jeopardizes the education of children who are victims of receiving instruction in a language that is not comprehensible to them. As reported by the ESA Unit (2005), in schools where the language policy was completely implemented, the academic performance of children in their later 3 years of primary school on the Monitoring of Learning Achievement Exercise were exceptionally higher than the children in schools where the policy has not been fully implemented. While the Federal Ministry of Education entrusted with the responsibility of coordinating and harmonizing education policies has no accountability measures to enforce the policy, other efforts have been invested in facilitating the implementation of the language policy in the country. One of the challenges of implementing the policy is that some minority Nigerian languages do not have written forms and the lack of materials for some native languages. Nigeria Educational Research and Development Council (NERDC) has accomplished some language development projects including the development of orthographies for 35 Nigerian languages in addition to the languages that have long had orthographies and curricula (Vanguard, 2010). Curricula for Nine Network Languages for both primary and senior secondary school levels, language textbooks and other instructional materials, and bilingual dictionaries including English-Hausa, English-Igbo and English-Yoruba for basic education have been developed by NERDC (Vanguard, 2010). Nevertheless, there is more to be done in ensuring that the language policy is implemented. Paucity of trained language teachers for both English and native languages is another factor that impedes the implementation of Nigeria language policy (UNESCO IBE, 2003). Consequently, states have resorted to using any available native speaker to teach the language in question (UNESCO IBE, 2003).

\section{Conclusion}

Language education policy planning could be complex in linguistic pluralistic countries such as Nigeria. One thing such countries must accept is that linguistic heterogeneity has become the order of the day in our 
contemporary globalized world and must be well-considered in educational planning. Two paramount aspects of effective bilingual education that a multilingual society like Nigeria is to consider in the planning its language education policy include making education accessible to all learners through bilingual instruction that reflects the language practices they bring to school and developing their bilingual skills for global competitiveness (Crawford, 2004; Garcia, 2009; Jong, 2006). A critical analysis of Nigeria's language policy revealed that Nigeria has taken a language-as-resource perspective toward language policy planning but has major drawbacks that have consequences for the preservation of the rich linguistic assets that students bring to school and meeting the educational needs of all students.

In Nigeria's language policy, students' native languages are temporarily welcomed and recognized as resources for making instruction comprehensible. Observed in the language policy is the goal to transition all students into all-English classrooms upon the completion of lower primary education regardless of whether they have attained English language proficiency or not This focus of the policy on transitioning students to English could either jeopardize their educational opportunities or lead to loss of Nigeria's native languages. Moreover, Nigeria's language policy has never been reviewed since 2004 or updated to match modern linguistic landscapes. The policy apparently needs to be transformed to match up with recent conceptualizations of bilingual education and to be in tune with the complex linguistic practices dominant in the country. This implies that planning for a comprehensive dynamic bilingual education is critical for Nigeria and must be prioritized. To make education accessible to all students and promotes bilingualism as an asset, Nigeria must consider a bilingual education model that less emphasizes transitioning students to English and focuses on promoting bilingualism and biliteracy with the goal to advance global economy and cultural enrichment and prepare learners for life in the 21 st century world where monolingualism has become obsolete (Crawford, 2004; Ruiz, 1988). Dynamic bilingual education comes as a fit for the Nigerian setting where students come to school from different linguistic backgrounds with diverse linguistic repertoires that are continually evolving and elastic (Alanis, 2000; Berens, et al., 2013;; Lara-Alecio, et al., 2004; López \& Tashakkori, 2006; Marian, et al., 2013; Murphy, 2014; Senesac, 2002).

A major challenge that Nigeria language policy faces is uneven implementation. In the course of the analysis, it was observed that what is spelt out in the language policies of Nigeria is far from what is practiced in schools. A trend in the majority of schools in Nigeria is providing students instruction in English only, even when it has been speculated in policies that they are to be provided native language instruction until the end of lower primary school. One responsible factor the unevenness in the implementation of the language policy is lack of accountability measures. Nigeria needs to set up accountability measures for the implementation of its language policy throughout the nation to encourage commitment to its goals in schools.

It was also found that paucity of bilingual teachers was a challenge to language policy implementation in Nigeria. This challenge may be considered minor as there is hardly a Nigeria who does not have a home language other than English. To address this challenge, teacher training programs in Nigeria can be supported to prepare teachers with skills and knowledge for addressing linguistic diversity in the classroom, create awareness of language diversity, as well as the importance of bilingual instruction and building students' bilingual skills. In addition, peerlingual education has been identified as an invaluable resource in cases where there are no teachers to offer native-language support to students (Johnson, 2011). Schools and educators are in direct contact with learners, and so understand the academic challenges they face. Rather than use their agentive power to enforce all-English instruction, they can begin to embrace students' language resources, build on, and expand them rather than remedy them (Avineri et al., 2015; Crawford, 2004; Dubertz \& de Jong, 2011; Johnson, 2015; Rolstad \& Macswan, 2008; Wiley \& Rolstad, 2014; Zentella, 2002). With this sort of orientation in place, Nigerian schools could start a commitment to bilingual education by using bilingual students as peer tutors to make learning comprehensible to their peers who share similar native languages.

\section{References}

Alanís, I. (2000). A Texas two-way bilingual program: Its effects on linguistic and academic achievement, Bilingual Research Journal, 24(3), 225-248.

Avineri, N., Johnson, E.J., Brice-Heath, S., McCarty, T., Ochs, E., Kremer-Sadik, T., Blum, S., Zentella, A.C., Rosa, J., Flores, N., Alim, H.S., \& Paris, D. (2015). Invited forum: Bridging the "language gap". Journal of Linguistic Anthropology, 25(1), 66-86.

Berens, M.S., Kovelman, I., \& Petitto, L. (2013). Should bilingual children learn reading in two languages at the same time or in sequence? Bilingual Research Journal, 36(1), 35-60.

Crawford, J. (2004). Educating English learners: Language diversity in the classroom (5 ${ }^{\text {th }}$ edition). Bilingual Education Services.

Cummins, J. (2017). Teaching minoritized students: Are additive approaches legitimate?. Harvard Educational Review, 87(3), 404-425.

Danladi, S.S. (2013). Language policy: Nigeria and the role of English language in the $21^{\text {st }}$ century. European 
Scientific Journal, 9(17).

Dubertz, N.E., \& de Jong, E.J. (2011). Teacher advocacy in bilingual programs. Bilingual Research Journal, $34(3), 248-262$

Education Sector Analysis Unit Federal Ministry of Education. (2005). Nigeria education sector diagnosis. Retrieved from http://planipolis.iiep.unesco.org/upload/Nigeria/Nigeria\%20 Education\%20 Sector\%20 Diagnosis.pdf

Faltis, C., \& Coulter, C. (2005). Bilinguaphobia in the new millennium. In Marketing Fear in America's Public Schools (pp. 161-174). Routledge.

Flores, N., \& Schissel, J. L. (2014). Dynamic bilingualism as the norm: Envisioning a heteroglossic approach to standards-based reform. TESOL Quarterly, 48(3), 454-479.

García, O. (2009) Education, multilingualism, and translanguaging in the 21st century. In T. SkutnabbKangas, R. Phillipson, A.K. Mohanty and M. Panda (eds.), Social Justice through Multilingual Education (pp. 140158). Multilingual Matters.

García, O., \& Sylvan, C. E. (2011). Pedagogies and practices in multilingual classrooms: Singularities in pluralities. The Modern Language Journal, 95(3), 385-400.

Hornberger, N. H. (2005). Opening and filling up implementational and ideological spaces in heritage language education. The Modern Language Journal, 89(4), 605-609.

Johnson, E.J. (2009). (Re)defining freedom of speech: Language policy, education, and linguistic rights in the United States. Journal of Applied Language Studies, 3(1), 3-23.

Johnson, E.J. (2011). Peerlingual education: A socioeducational reaction to structured English immersion. Journal of Latinos and Education, 10(2), 127-145.

Johnson, E.J. (2015). Debunking the "language gap". Journal for Multicultural Education, 9(1), 42-50.

Johnson, D.C., \& Johnson, E.J. (2015). Power and agency in language policy appropriation. Language Policy, 14(3), 221-243.

Jong, E. (2006). Integrated bilingual education: An alternative approach. Bilingual Research Journal, $30(1)$, 2344.

Khote, N., \& Tian, Z. (2019). Translanguaging in culturally sustaining systemic functional linguistics: Developing a heteroglossic space with multilingual learners. Translation and Translanguaging in Multilingual Contexts, 5(1), 5-28.

Lara-Alecio, R., Galloway, M., Irby, B.J., Rodríguez, L., \& Gómez, L. (2004). Two-way immersion bilingual programs in Texas. Bilingual Research Journal, 28(1), 35-54.

López G. \& Tashakkori, A. (2006). Differential outcomes of two bilingual education programs on English language learners. Bilingual Research Journal, 30(1), 123-145.

Malagon, H., \& Chacon, A. (2009). Washington state transitional bilingual instruction program guidelines. Report prepared for: Special Programs \& Federal Accountability, Office of Superintendent of Public Instruction, Migrant \& Bilingual Education. Available at: www.k12.wa.us/migrantbilingual/pubdocs/TBIPProgramGuidelines.pdf

Marian, V., Shook, A., \& Schroeder, S. R. (2013). Bilingual two-way immersion programs benefit academic achievement. Bilingual Research Journal, 36(2), 167-186.

McCarty, T. L. (2004). Dangerous Difference: A Critical-Historical Analysis of Language Education Policies in the United States. In Tollefson, J.W. \& Tsui, A.M.B. (eds.), Medium of Instruction Policies: Which Agenda? Whose Agenda? Lawrence Erlbaum Associates, 71-96.

Murphy, A. F. (2014). The effect of dual-language and transitional-bilingual education instructional models on Spanish proficiency for English language learners. Bilingual Research Journal, 31 (2), 182-194.

Ngai, P. B. (2002). Bilingual education for all: A benefits model for small towns. Bilingual Research Journal, 26(2), 269-294.

Nigerian Muse. (2010). Ethnic minority groups in Nigeria: Current situation and major problems. Retrieved from http://www.nigerianmuse.com/20101205024305zg/sections/general-articles/ethnic-minority-groups-innigeria-current-situation-and-major-problems-by-abdul-raufu-mustapha/

Odugu, D.I. (2011). Education language policy process in multilingual societies: Global visions and local agendas in India, Nigeria and UNESCO. Loyola University, Chicago.

Office of the Superintendent of Public Instruction. (2011). A Call for Equity and Excellence foe ELLs in Washington $\quad$ State. Retrieved from http://www.k12.wa.us/MigrantBilingual/pubdocs/BEACPositionPaper2011.pdf

Office of the Superintendent of Public Instruction. (2014). A Call for Equity and Excellence foe ELLs in Washington State. Retrieved from http://www.k12.wa.us/MigrantBilingual/PositionPaper.aspx

Office of the Superintendent of Public Instruction. (2015a). Update: Transitional Bilingual Instruction Program (TBIP) 2013 - 2014. Retrieved from http://www.k12.wa.us/LegisGov/2015documents/TBIPJan2015.pdf

Office of the Superintendent of Public Instruction. (2015b). Washington State Transitional Bilingual Instruction 


$\begin{array}{lllll}\text { Program } & \text { Models } & \text { and } & \text { Services. } & \text { Retrieved }\end{array}$
http://www.k12.wa.us/MigrantBilingual/pubdocs/ProgramModels.pdf

Ojetunde, F. (2012). A critical evaluation of the implementation of the Nigerian language policy at the preprimary and primary school levels. Journal of Education Practice, 3(16).

Ovando, C.J. (2003). Bilingual education in the United States: Historical development and current issues. Bilingual Research Journal, 27(1), 1-24.

Rolstad, K., \& MacSwan, J. (2008). BICS/CALP theory. In S.L. McKay \& S.C. Wong (Eds.) Language diversity: Problem or resource? (pp. 3-25). Newbury House.

Rolstad, K., Mahoney, K.S., \& Glass, G.V. (2005). Weighing the evidence: A meta-analysis of bilingual education in Arizona. Bilingual Research Journal, 29(1), 43-67.

Ruiz, R. (1988). Orientations in language planning. In S.L McKay \& S.C. Wong (Eds.), Language diversity: Problem or resource? (pp. 3-25). New York, NY: Newbury House.

Sayer, P. (2008). Demystifying language mixing: Spanglish in school. Journal of Latinos and Education, 7(2), 94-112.

Senesac, B.V. (2002). Two-way bilingual immersion: A portrait of quality schooling, Bilingual Research Journal, 26(1), 85-101.

U.S. Census Bureau, (2010). Language Use in the United States: 2007. Retrieved from http://www.census.gov/hhes/socdemo/language/data/acs/ACS-12.pdf?cssp=SERP

U.S. Census Bureau, (2015). State \& County QuickFacts. Retrieved from http://quickfacts.census.gov/qfd/states/53000.html?cssp=SERP

United States Department of Education. (2007). Assessment and accountability for recently arrived and former limited English proficient (LEP) students: Non-regulatory guidance. Retrieved from http://www2.ed.gov/admins/lead/account/sea.html\#Related_Regulations_and_Guidance

United Nations Educational, Scientific and Cultural Organization. (2003). Strategies for introducing new curricula in West Africa: Final report of the seminar/workshop held in Lagos, Nigeria, 12 - 16 November, 2001. Retrieved from http://www.ibe.unesco.org/fileadmin/user_upload/archive/curriculum/AfricaPdf/lagorepo.pdf

United Nations Educational, Scientific and Cultural Organization. (2006). World data on education (6 ${ }^{\text {th }}$ edition). Retrieved from http://www.ibe.unesco.org/fileadmin/user upload/archive/Countries/WDE/2006/SUBSAHARAN_AFRICA/Nigeria/Nigeria.htm

Vance, C.W. (2004). Preparing a prosperous future: Promoting culture and business through bilingual education, Bilingual Research Journal, 28(3), 463-483.

Vanguard. (2010). Educational stakeholders brainstorm on national language policy. Retrieved from http://www.vanguardngr.com/2010/06/education-stakeholders-brainstorm-on-national-language-policy/

Villarreal, A. (1999). Rethinking the education of English language learners: Transitional Bilingual education. Bilingual Research Journal, 23(1), 11-46.

Wiley, T.G., \& Rolstad, K. (2014). The Common Core Standards and the great divide. International Multilingual Research Journal, 8(1), 38-55.

Woodward, T. (2001). Planning courses and lessons: Designing sequences of work for the language classroom. United Kingdom: Cambridge University Press.

World Education News and Review. (2004) Education in Nigeria. Retrieved from http://wenr.wes.org/2004/09/wenr-septemberoctober-2004-education-in-nigeria/

Zentella, A.C. (2002). Latin@ languages and identities. In M.M. Suárez-Orozo \& M.M. Páez (Eds.), Latinos: Remaking America (pp. 321-338). University of California Press. 